\title{
Prosesing Dan Legalitas Kopi Dalam Pemberdayaan UMKM Di Desa Panduman Kecamatan Jelbuk Kabupaten Jember
}

\author{
Wiwit Widiarti, Menik Chumaidah dan Iskandar Umarie \\ Universitas Muhammadiyah Jember \\ Email:wiwit.widiarti@unmuhjember.ac.id,iskandarumarie@unmuhjember.ac.id, \\ menikchumaidah@unmuhjember.ac.id
}

Diterima: Mei 2021 | Dipublikasikan: Juni 2021

\begin{abstract}
ABSTRAK
Desa Panduman merupakan salah satu desa di kecamatan Jelbuk kabupaten Jember dengan ketinggian 700-800 m dpl. Ketinggian tersebut sangat cocok bagi budidaya kopi. Luasan kebun kopi di dusun Sumbercandik 293 Ha dan mayoritas dimiliki petani. Umumnya kopi yang dihasilkan belum mengalami pengolahan artinya dijual secara glondongan dengan harga yang sangat rendah, akibatnya sebagian petani mengalami kerugian. Permasalahan ini mendorong kami melalui pembentukan kelompok tani kopi (UMKM) untuk meningkatkan nilai jual kopi melalui prosesing yang bersinergi dengan BUMD. Diskusi awal dilaksanakan pada bulan Pebruari dengan mendatangkan petani untuk menggali permasalahan yang sangat urgen, meliputi : belum adanya pengolahan kopi, banyaknya kotoran kambing dan keberlanjutan program. Program Kemitraan masyarakat stimulus menjawab permasalahan tersebut yang dilaksanakan selama 3 bulan dimulai bulan Januari - Maret 2021 dengan dibantu dua orang mahasiswa. Sosialisasi dan pelatihan dilaksanakan pada tanggal 2 Maret 2021 di balai desa Panduman diikuti oleh 15 orang terdiri dari Karang Taruna, petani kopi dan BUMD. Materi yang disampaikan meliputi : Prosesing kopi, pembuatan biogas dan pembentukan kelompok Tani. Pendampingan dilakukan melalui diskusi di whast ap grup mengingat masih masa Pandemi Covid 19. Diharapkan melalui pelatihan, petani kopi dusun Sumbercandik dapat lebih sejahtera dengan meningkatnya nilai jual kopi.
\end{abstract}

Kata Kunci: kopi, prosesing, dusun Sumbecandik

\section{ABSTRACT}

Panduman is one of the village in Jelbuk Jember with an altitude 700-800 $\mathrm{m}$ above sea level. This altitude is very suitable for coffee cultivation. The area of the coffe plantation in Sumbercandik is 293 hectares and the majority is owned by farmers. Generally, the coffe produced has not undergone processing, meaning that it is sold in bulk at a very low price, as a result some farmers suffer losses. This problem encourages us through the formation of coffe farmer groups to increase the selling value of coffe through processing in synergy with BUMD. The initial discussion was held in February by bringing in farmers to explore very urgent problems, including : the low of coffe processing, the amount of goat manure and the sustainibility of the program.The Stimulus Community Partnership Program answers these problems wich will be carried out for 3 months starting form January to March 2021 with the assistance of two students. Socialization and training were held on March 2, 2021 at the Panduman hall attended by 15 people consisting of youth Organization, coffe farmers and BUMD. The material presented includes : coffee processing, biogas production and the formation of farmer groups. Assistance was carried out through discussions on the whast ap group considering that it was still the Covid 19 Pandemic. It is hoped that through the training, Sumbercandik hamlet coffe farmers can be more prosperous by increasing the selling value of coffe

Keywords: coffee, processing, Sumbercandik hamlet

\section{PENDAHULUAN}

Desa Panduman merupakan salah satu desa di kecamatan Jelbuk dan terletak di sebelah Utara Kabupaten Jember. Kecamatan Jelbuk berbatasan dengan kecamatan Maesan kabupaten Bondowoso di sebelah Utara dan Timur Laut. Sebelah Timur berbatasan dengan kecamatan Sukowono dan kecamatan Kalisat. Sebelah Selatan kecamatan Arjasa dan sebelah Barat Kecamatan Panti (Potensi Kecamatan Jelbuk, 2018). Ketinggian tempat desa Panduman 700-800 
$\mathrm{m}$ di atas permukaan laut. Ketinggian tempat tersebut sangat cocok bagi budidaya kopi, terutama kopi jenis Robusta. Luasan kebun kopi di desa Panduman, sekitas 293 Ha dan mayoritas petani memiliki kebun kopi.

Potensi kopi di kecamatan Jelbuk cukup bagus dan dari tahun ke tahun mengalami fluktuasi. Produksi perkebunan kopi di kecamatan Jelbuk pada tahun 2017 sebesar 70 ton/tahun. Pada tahun 2018 mengalami sedikit penurunan menjadi 10 ton/tahun, sedangkan tahun 2019 mengalami peningkatan yang cukup tajam yaitu sebesar 600 ton/ha (BPS, tahun 2019). Kopi merupakan minuman yang sangat populer di Indonesia dengan pilihan kopi-kopi yang sudah mulai membangun citra merek seperti Kopi Arabika, Kopi Robusta dan macam-macam kopi lainnya. Masyarakat Desa Panduman bekerja sebagai petani yang sebagian besar menanam kopi. Kopi-kopi seperti Robusta sangat tepat menjadi pilihan para Petani disana, karena kopi tersebut membutuhkan cuaca yang dingin seperti menanam di gunung. Umumnya produksi kopi yang dihasilkan belum mengalami pengolahan artinya masih dijual secara gelondongan.

Penjualan kopi secara gelondongan apalagi tanpa adanya sortasi (pemisahan) kopi, artinya para petani masih menjual kopi secara utuh baik kopi yang masih berwarna hijau, kuning maupun yang merah, sehingga harganya sangat murah bahkan ada petani yang mengalami rugi. Dalam setahun umumnya petani panen satu kali dan yang sangat mengkhawatirkan adalah $90 \%$ dari petani menjual kopinya ke tengkulak. Keberadaan kopi di desa Panduman belum terekspose dan belum terkenal di masyarakat luar. Permasalahan ini yang mendorong kami untuk meningkatkan nilai jual kopi melalui pembentukan kelompok tani kopi, prosesing, packing bahkan pengurusan PIRT ke dinas Kesehatan maupun Disperindag sehingga kopi yang dihasilkan oleh petani di desa Panduman kecamatan Jelbuk mempunyai nilai jual yang tinggi dan dapat meningkatkan profit dari petani tersebut.

Umumnya kopi yang dipasarkan tidak disortasi oleh petani, sehingga kopi yang diperdagangkan masih mengandung sebagian bahan yang dapat menurunkan mutu kopi (Ismayadi dan Zainudin, 2003). Terdapat peluang pengembangan kopi dan perbaikan mutu kopi rakyat melalui teknologi pengolahan kopi kering. Berdasarkan cara kerjanya, pengolahan buah kopi dibedakan menjadi dua yaitu pengolahan basah (wet process) dan kering (dry process) (Bonita, et al, 2007). Pengolahan cara kering biasanya dilakukan petanim kopi (rakyat) karena dapat dilakukan dengan peralatan sederhana.Cara pengolahan ini meliputi panen, sortasi buah, pengeringan, pengupasan, sortasi biji kering, pengemasan dan penyimpanan biji kopi.

\section{METODE PELAKSANAAN}

Pengabdian masyarakat telah dilaksanakan selama 3 bulan yaitu mulai bulan Januari sampai Maret 2021 di desa Panduman kecamatan Jelbuk kabupaten Jember dengan melibatkan 2 orang mahasiswa dan 15 orang terdiri dari petani kopi yang terhimpun dalam komunitas petani kopi (UMKM), karang taruna dan BUMD. Tahapan prosedur kerja, dapat dilihat pada Gambar 1.

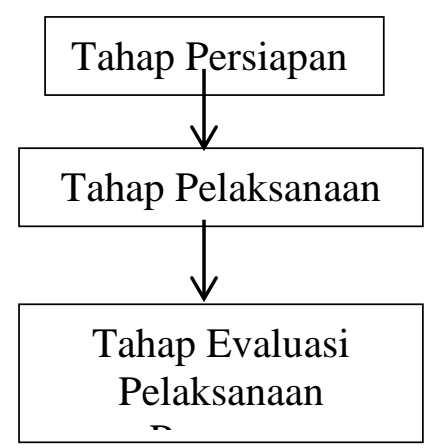

Gambar 1. Tahapan prosedur kerja pengabdian masyarakat.

Tahap persiapan dilakukan untuk menggali lebih dalam tentang permasalahan mendasar yang memang dibutuhkan oleh petani dengan mengumpulkan perwakilan petani sejumlah 6 
orang di Balai desa Panduman pada tanggal 1 Pebruari 2021. Hasil dari diskusi didapatkan bahwa ada tiga potensi dan permasalahan yang bisa dikembangkan dalam bentuk pelatihan, yaitu :

1. Petani masih menjual kopi secara gelondongan dengan harga yang sangat murah, untuk kopi Robusta harga per kg kopi, Rp. 5.000, sedangkan Arabika Rp. 10.000, sehingga perlu dilakukan prosesing terhadap kopi.

2. Sebagian besar petani memiliki ternak kambing dimana kotoran kambing belum dimanfaatkan secara optimal, sehingga perlu dilakukan pengolahan terhadap kotoran kambing dalam bentuk biogas.

3. Untuk keberlanjutan program, maka perlu dibentuk kelompok UMKM bersinergi dengan BUMDES

\section{HASIL DAN PEMBAHASAN}

Berdasarkan permasalahan yang ada di petani, maka perlu dilakukan sosialisasi dan pelatihan guna meningkatkan pemahaman petani bahwa sebaiknya kopi dipetik ketika sudah merah sampai hitam karena hal ini sangat berpengaruh pada kualitas kopi. Selama ini petani dusun Sumbercandik desa Panduman melakukan pemetikan kopi secara menyeluruh artinya tidak ada sortasi. Seharusnya hanya buah kopi yang berwarna merah saja yang dipetik. Para petani juga menjual kopi secara gelondongan baik pada kopi Robusta maupun Arabika sehingga harga sangat rendah bahkan ada yang mengalami kerugian. Oleh karena itu perlu dilakukan sosialisasi dan pelatihan guna meningkatkan nilai jual kopi. Adapun sosialisasi dan Pelatihan dilaksanakan pada hari Selasa tanggal 2 Maret 2021 bertempat di Balai Desa Panduman kecamatan Jelbuk kabupaten Jember, diikuti oleh 15 orang peserta berasal dari Karang Taruna, petani dan BUMDES. Agar pelatihan dapat berjalan dengan baik dan lancar, maka kami dibantu oleh dua orang mahasiswa yang berasal dari program studi Agroteknologi fakultas Pertanian Universitas Muhammadiyah Jember. Sosialisasi dan Pelatihan dilaksanakan dengan dengan mendatangkan 2 orang pemateri yaitu :

Materi pertama disampaikan oleh Dr. Ir. Teguh Hari Santoso, MP yang menjelaskan tentang prosesing kopi. Inti dari prosesing kopi dapat dilihat pada Gambar 2.

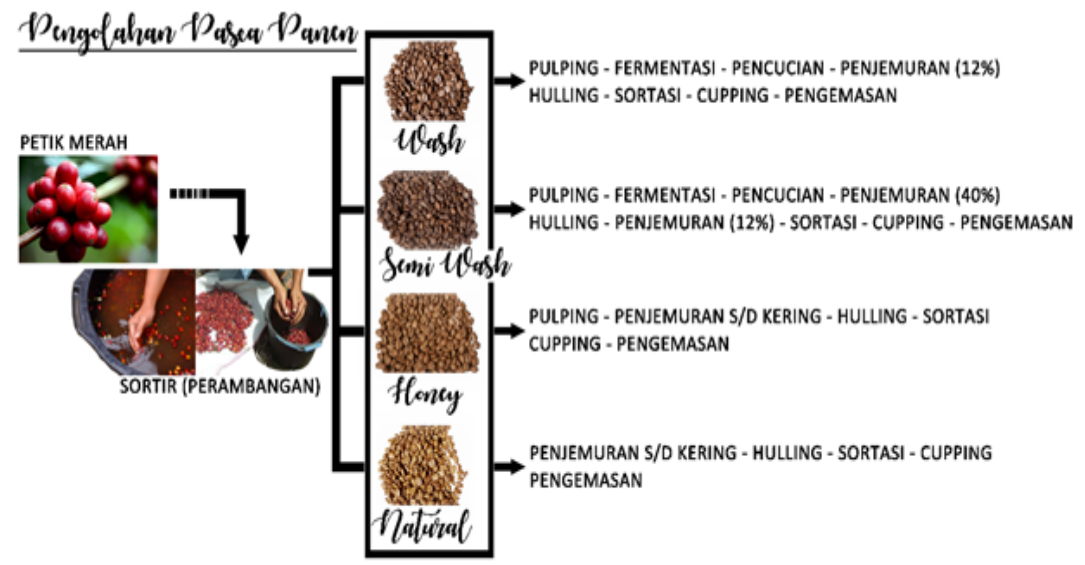

Gambar 2. Tahapan Prosesing Biji Kopi

Materi kedua disampaikan oleh Ir. Iskandar Umarie, MP yang menjelaskan tentang pemanfaatan kotoran kambing dalam bentuk biogas. Selain itu produk samping dari biogas adalah pupuk organik baik berupa pupuk padat maupun pupuk cair yang dapat dimanfaatkan untuk menyuburkan tanah di lahan pertanian. 
Adapun Diagram Alir Proses fermentasi An aerobik pada pembuatan biogas dapat dilihat pada Gambar 3.

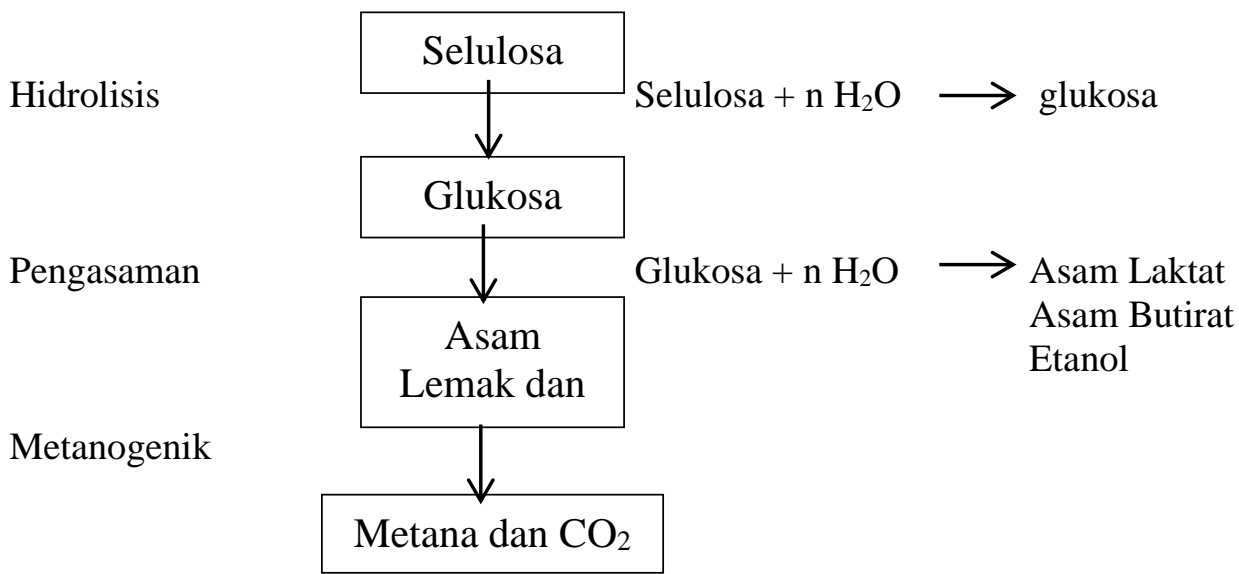

Gambar 3. Diagram Alir Proses Fermentasi An aerobik pada pembuatan Biogas

Produksi biogas dipengaruhi oleh : $\mathrm{C} / \mathrm{N}, 20-30, \mathrm{pH}$ asam (6-7), kadar air dan suhu (25$35^{\circ} \mathrm{C}$ ), kandungan total padat dan ukuran biogas. Apabila $\mathrm{C} / \mathrm{N}$ terlalu tinggi, nitrogen akan dikonsumsi dengan cepat oleh bakteri metanogenik untuk pertumbuhannya dan hanya sedikit yang beraksi dengan karbon.

Di akhir pertemuan dilakukan pembentukan kelompok yang diberi nama Kelompok Tani (UMKM) Sukmo Ilang dusun Sumbercandik. Tahap evaluasi dilakukan setelah pelaksanaan sosialisasi dan pelatihan. Dengan terbentuknya kepengurusan, maka dilakukan tindak lanjut berupa grup whast app yang beranggotakan TIM pengabdian pada masyarakat, seluruh pengurus dan sekretaris desa sebagai admin. Selanjutnya pendampingan dilakukan melalui diskusi di dalam grup tersebut mengingat saat ini masih masa pandemi Covid 19.

\section{KESIMPULAN DAN SARAN}

Dusun Sumbercandik yang terletak di pegunungan sangat potensial untuk budidaya kopi, sehingga harus didukung oleh meningkatnya pengetahuan dan ketrampilan petani terutama dalam hal prosesing kopi. Hal ini sangat berarti dalam guna menghasilkan kopi yang berdaya simpan lebih lama sehingga mempunyai nilai jual yang tinggi, tidak lagi menjual secara gelondongan. Kelompok tani (UMKM) Sukmo Ilang harus bersinergi dengan BUMD guna keberlanjutan program terutama dalam hal mengupayakan sarana (alat) yang dibutuhkan di dalam prosesing kopi.

\section{UCAPAN TERIMA KASIH}

Terima kasih kami ucapkan kepada Lembaga Penelitian dan Pengabdian kepada Masyarakat (LPPM) Universitas Muhammadiyah Jember yang telah membiayai melalui Program Kemitraan Masyarakat Stimulus (PKMS) sehingga kegiatan ini dapat berlangsung dengan lancar. 


\section{DAFTAR PUSTAKA}

Badan Pusat Statistik, 2019. Produksi Perkebunan Menurut Kecamatan dan Jenis Tanaman di Kabupaten Jember (ribu ton)

Bonita, J.S., Mandarano, M., Shuta, D. and Vinson, J., 2007. Coffee and cardiovascular disease: in vitro, cellular, animal, and human studies. Pharmacological research, 55(3), pp.187198.

Ismayadi, C., Zaenudin. 2003. Pola produksi infestasi jamur, dan upaya pencegahan kontaminasi okratoksin-A pada kopi Indonesia. Simposium Kopi. 